\title{
The cell system of Giardia lamblia in the light of the protist stem cell biology
}

Vladimir F. Niculescu

Correspondence: besnea@aol.com

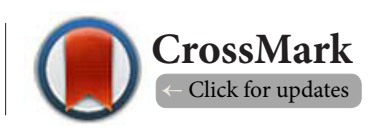

Kirschenweg 1, 86420 Diedorf, Germany.

\begin{abstract}
Cell differentiation in Entamoeba and Giardia exhibit a great deal of similarity. Unfortunately, both protists were studied over the years mostly under axenic conditions, disregarding the natural micro-ecology of host intestine. Using hypoxic culture sediments with oxygen consuming bacteria (OCB niches) we discovered in E. invadens an ancient stem cell system that shows the same basal mechanisms for stemness that exist in highly developed stem cell systems too. The ancient stem cells of E. invadens (AnSC) have all standards of the stem cell definition (self renewing and quiescent cells, glycolytic metabolism, stem cell plasticity, reprogramming and induced totipotency recovery, and both induced and autonomous terminal differentiation) indicating that stem cells were developed by the anaerobe proterozoic LECA-as stages of its life cycle-then diverged into all eukaryotes. The more protist stem cell systems we can dechipher the more we will learn about the ancestral protolineage, its cell line hierarchy and basal mechanism of stemness. We assume that Giardia could be a good model system to expand protist stem cell biology. We found in Giardia literature evidence suggesting self renewal and quiescence, plasticity and other stem cell characteristics. The present study is a reinterpretation of Giardia's life cycle in the light of current stem cell knowledge. It is hoped this reinterpretation stimulates new developments.
\end{abstract}

Keywords: LECA, Entamoeba, Giardia, life-cycle, stem cells, stem cell lines, induced and autonomous mechanisms for terminal differentiation

\section{Introduction}

In the last 20 years stem cell biology has made enormous progress. Most advances are a result of medical research, in particular from studies on embryonic stem cells (ESC), haematopoietic stem cells (HSC) and cancer stem cells (CSC). HSC were established as the prototypical stem cells capable of nearly indefinite self renewal and differentiation [1]. This basal definition permits one to identify a variety of other stem cells in other tissues and organisms and also in Entamoeba and Giardia. Both protists meet the current criteria of ancient stem cells (AnSC). Until recently the origin and the beginning of stemness remains an enigma $[2,3]$. Before AnSC were discovered in pathogen protists [4-6] little is known about the evolutionary origin of stem cells, when stem cells appeared and why. The basal mechanisms of stemness discovered in E. invadens [4-7] clearly indicate the anaerobe LECA as the initiator of stemness. It is the great-grandfather of all eukaryotic stem cell lineages. The ancestral stem cell protolineage of LECA-best conserved in
E. invadens-shows that stem cells appeared as individual stages in the life cycle of the single-celled organisms [6].

The ancient stem cell plasticity certainly had different roles than the stem cell plasticity of highly evolved human and mammalian stem cell systems. In humans there are three rigid criteria for stem cell plasticity: (i) capacity of a unique cell to differentiate into multiple cell lineages, (ii) robustness and (iii) persistence of differentiated cells [8-10]. Other than human stem cells, protist's AnSCs represent transient evolutive stages of the vegetative life, in other words it represents the entire organism in different stages of its life cycle. Plasticity means in AnSC systems the differentiation of a totipotent innercyst cell into an hierarchical organized stem cell protolineage including (i) distinct stem cell lines with specific functions and differentiation capacities (ii) potency restriction from totipotency to unipotency (iii) recovery of totipotency by terminal differentiation and (iv) permanent switching from one metabolic pathway to an other when niche $\mathrm{pO} 2$ values are changing. AnSCs of $E$. 
invadens can co-habitat in multicellular communities. All cells co-operate by phagocytosis to modify the oxygen values of the OCB niche $[\mathbf{5}, \mathbf{6}]$ thus initiating stimuli for lineage development. In vivo pathogen protists look for suitable niches where they create local hypoxia via inflamation processes. If the low oxygen level that they require is achieved, AnSCs behave as human stem cells in their own niche. The basal mechanisms of stemness are the same. In the following we search the existent Giardia literature for evidence and analogies to the cell lines and stemness observed in E. invadens.

\section{Materials and methods}

The authors we reviewed cultured Giardia in TYI-S-33 media enriched with $1.0 \mathrm{mg} / \mathrm{ml}$ bovine bile or not, and transferred cells for induced encystment in "encysting" medium containing $10 \mathrm{mg} / \mathrm{ml}$ bovine bile ${ }^{*}[16,44,55,56]$. In the present paper we call these media CM/WBB ("pre-encysting" culture medium without bovine bile), CM/BB1.0 (culture medium with $1 \mathrm{mg} /$ $\mathrm{ml}$ bovine bile medium) and CM/BB10 (encysting medium with $10 \mathrm{mg} / \mathrm{ml}$ bovine bile).

*Concentration given in $\mathrm{mg} / \mathrm{ml}$ by Keister [55] and Kane et al., [56]; in $\mathrm{mg} \mathrm{ml}^{-1}$ by Sulemana [16]; in $\mathrm{g} \mathrm{m}^{-1}$ by Reiner et al [44].

\section{Results and discussion}

\section{The standard model of protist stem cell biology}

Asymmetric division is the premise for stemness and multicellularity and therefore a significant feature in stem cell and differentiation biology. As observed in E. invadens protist AnSC divide asymmetrically giving rise to two non-identical daughter cells: a new self-renewing cycling stem cell SRC (D1 daughter cell) and a reversible differentiated mitotic arrested cell MAC (D2 daughter cell, quiescent cell) exiting cell cycle in a G0 state. Stem cell differentiation in protists was first reported in E. invadens [4-6] grown in hypoxic sediments with oxygen consuming bacteria (OCB) [7].

E. invadens' lineage is considered currently, as a standard model for protist stem cell biology. It is a three stem cell line system (PST lineage) consisting of primary ( $p-S R L)$, secondary ( $\mathrm{s}-\mathrm{SRL}$ ) and tertiary ( $\mathrm{t}-\mathrm{SRL}$ ) self-renewing stem cell lines controlled by niche hypoxia, $\mathrm{pO} 2$ and environmental stimuli. Some of the stem cell lines are non continuous lines ( $p-S R L$, $s-S R L)$ while $t-S R L$ is a continuous stem cell lines, proliferating infinitely. The primary $\mathrm{p}$-SRL produces reversible differentiated MAP cells as reserve stem cells (RSC), the secondary s-SRL pro- duce MAS cells for autonomous terminal differentiation and ATD encystment and the tertiary t-SRL give rise to quiescent MAT cells capable for induced terminal differentiation and ITD cyst formation (see Table 1 ).

E. invadens develops a stem cell differentiation network containing mechanisms for autonomous and induced terminal differentiation that give rise to ATD and ITD cysts. The ability to form cysts by different mechanisms distinguishes the secondary ATD cysts producing line s-SRL/ATD from the tertiary t-SRL(ITD) line capable of ITD encystment. In contrast to basal metazoans for example Hydra [11] protist stem cell lines have a well defined stem cell hierarchy and can interconvert one to the other within an integrated lineage $(P / S$, $\mathrm{P} / \mathrm{T}$ and $\mathrm{S} / \mathrm{T}$ conversion) $[3,5,6]$. Stem cell line conversion in $E$. invadens is induced by oxidative stress or hypoxia. Primary $\mathrm{P}$ cells may convert environmental-dependant to $S$ or T cells (P/S or $\mathrm{P} / \mathrm{T}$ conversion). The non-continuous S-SRL line converts by $S / T$ conversion to the continuous t-SRL. $t-S R L$ is the only continuous stem cell line, surviving in optimal living conditions infinitely. By passaging in subcultures MAT cells re-enter cell cycle replenishing the own cell line.

In E. invadens the tetranucleated innercyst cell is the totipotent progenitor cell for a new round of life. It hatches into culture medium and divides by cytokinesis to four uninucleated amoebulae (A1 cells). The four A1 cells replicate and divide symmetrically to eight A2 cells. In hypoxic growth conditions A2 cells decide for stemness [6] and convert by $A 2 / P$ conversion to primary stem cell predecessors (PDP) that decide the asymmetric cell fate. In the next 4-5 days, cycling SRP cells progress in the cell cycle maintaining the $p$-SRL line constant, while MAP cells arrested in G0 state. By repeated asymmetric division the MAP fraction increases progressively to a dominant quiescent sub-population. The metacystic development of $E$. invadens contains a sequence of transient cell types descending from the innercyst cell (innercyst $\rightarrow A 1$ cells $\rightarrow$ A2 cells $\rightarrow$ PDP cells $\rightarrow$ SRP cells (D1) $\rightarrow$ MAP cells (D2).

Both ATD and ITD encystment events takes place from the G1 phase. In particular, T cells exhibit a rather complex encystment behaviour. At the beginning of cell cycle progression daughter T cells (D1, D2 cells) are in a state of double potency and can be induced for ITD encystment if not mitotically determined. Double potency applies both to SRT cells prior to restriction point RP (G1 checkpoint) and to reversible differentiated MAT cells in G0 state. During the state of double

Table 1. The ancient hypoxic stem cell system of Entamoeba invadens.

\begin{tabular}{lllllll}
\hline Cell line & Cell type & $\begin{array}{l}\text { Conversion } \\
\text { capacity }\end{array}$ & $\begin{array}{l}\text { Self renewing } \\
\text { cells (D1) }\end{array}$ & $\begin{array}{l}\text { Cell cycle duration, } \\
\text { AGT (in hrs) }\end{array}$ & $\begin{array}{l}\text { Mitotic arrested } \\
\text { cells (D2) }\end{array}$ & $\begin{array}{l}\text { Terminal } \\
\text { differentiated cyst }\end{array}$ \\
\hline p-SRL & P & P/S, PT & SRP & AGT/6-24 & MAP* & -- \\
t-SRL & T & -- & SRT & AGT/6-24 & MAT & ITD \\
s-SRL & S & S/T & SRS & AGT5-6 & MAS & ATD \\
\hline
\end{tabular}

${ }^{\star}$ MAP, RSC: Reserve primary stem cells; ${ }^{* *}$ MAS, committed precysts; AGT: Average generation time 
potency both cell types may be induced by strong hypoxic $O C B$ sediments of the AaEM encystment medium to ITD (encystment ratio 1:1), however, ITD encystment doesn't take place when hydroxiurea was added (HUEM). The results indicate that mitotically non determined D1 cells in G1 phase, before becoming SRT, and MAT (D2) cells in G0 phase need for ITD encystment additional rounds of DNA synthesis (endoreplication) before they give rise to mature tetra-nucleated $4 C$ cysts. Few cells start cyst wall synthesis in HUEM (unpublished data), however, without forming surviving cysts. With other words, 4C ploidy is induced in T cells by extrinsic signaling mechanisms. Endoploidization to four genome copies take place outside the normal mitotic replication.

In conditions of strict hypoxia T cells convert in culture to symmetric cell fate. Identical strict hypoxic proliferating cells (ISHP cells) proliferate by slow cycling and arrest in G2/M when $\mathrm{SH}$ hypoxia slightly decreased. When induced for encystment ISHP/G2 cells divide in two identical daughter cells and each of the daughter cell encyst (encystment ratio 1:2). It is unclear whether ploidization take place in ISHP cells before symmetric division occurs or first when ISHP/G2 cells are induced for ITD encystment. We agree with Dübel and Schaller [38] who maintain that several cell types can be induced in G2 phase to undergo final mitosis and subsequent differentiation. Finally, it remains to be clarified if $4 C$ ploidization of autonomous encysting SRS cells in culture occurs before or after precyst commitment.

\section{Cell differentiation in Giardia}

In Giardia literature cell differentiation currently refers to a sequence of events separate from proliferation, restricted to encystment or excysting features. Terms such as "differentiation associated antigenic variation" and "stage-specific antigenic variations" described antigen switching in cells entering or exiting the dormant part of the life cycle. In our opinion encystment is a process of terminal differentiation (TD) ending the vegetative life cycle. In consequence, ex-cystment is rather a process of de-differentiation and return to undifferentiated stem cells. Cell differentiation processes occurring during the vegetative life cycle and proliferation are completely ignored in Giardia literature. However, vegetative cell differentiation occurs permanently in vivo as well as in vitro. Whether Giardia is cultured in axenic TYI-S-33 media with or without beef serum (BS) or bovine bile (BB) as adjuvants, the resulting long term populations are always heterogeneous, containing a mixture of different cell types. This heterogeneity includes stem cells and specific cell lines of various encystment potency and antigenicity. They are coated with specific surface antigens (VSP), apparently acting as markers in Giardia's lineage.

\section{Dediferentiation of the innercyst cell}

In Giardia's natural habitat, terminal differentiation (encystment) is triggered when trophozoites migrate from the duodenum to the distal ileum and encyst. Cholesterol progressively decreases and environmental changes caused by bacteria expose Giardia to multiple stimuli, but little is known about the complex interactions that controll Giardia's development within the natural environment $[12,13]$. Its intrinsic and extrinsic developmental mechanisms are poorly understood. Ex-cystation is facilitated in vitro by proteases and acidic $\mathrm{pH}$ (1.3 to 2.7), however an acidic $\mathrm{pH}$ is not obligatory. In G. muris excystation occurs in phosphate buffer with bicarbonate at $\mathrm{pH} 7.5$ [14]. When started under favorable conditions ex-cystation is rapidly completed in about $10 \mathrm{~min}$. The excysted tetranucleated $16 \mathrm{~N}$ innercyst cell $(4 \times 4 \mathrm{~N}$ cell) named excyzoite enters a phase of ploidy reduction and phenotypic modification. It undergoes cytokinesis within 15-30 min [15] giving rise to two binucleated $8 \mathrm{~N}$ trophozoites ( $2 \times 4 \mathrm{~N}$ cells) [16]. Further ploidy reduction occurs by nuclear division and each $8 \mathrm{~N}$ cell divides by cytokinesis to two $4 \mathrm{~N}$ cells $(2 \times 2 \mathrm{~N}$ cells), giving a total of four $4 \mathrm{~N}$ cells per cyst. The four $4 \mathrm{~N}$ cells of Giardia correspond functionally to the eight A2 amoebulae of E. invadens. We suspect that Giardia's A2 cells enter cell cycle and convert to primary PDP predecessor cells by A2/P conversion. It is unclear if PDP cells leave the cell cycle by an asymmetric division which gives rise to non-identical primary $P$ cells (distinct D1 and D2 daughter cells) or by symmetric division which gives rise to identical progeny. It is also not known whether the primary population (P cells) proliferates in Giardia first by asymmetric or symmetric division. In contrast to E. invadens, Giardia has probably an increased capacity to switch back and forth between symmetric (logarithmic) and asymmetric (non-logarithmic) proliferation, changing thus from apparently identical cells to non-identical daughter cells (distinct D1 and D2 cells).

\section{Stage-specific marker}

The molecular mechanisms for antigenic switching and cell line conversion are inherited probably from the common ancestor. Surface antigen variation is evolutionarily determined and is a common characteristic in the protist kingdom. It was described in free-living protists such as Paramecium [17-19] and Tetrahymena [20] and pathogen protists [21] such as Trypanosoma cruzi [22,23] and T. brucei [24-26], Leishmania [27], Plasmodium [28,29], E. histolytica [30] and Giardia. Giardia coating antigens belong to a unique protein family, the variant-specific surface antigens VSP [31,32]. Individual strains, isolates and variants basically produce a single VSP as major coating exo-product, which is also released into the culture medium [33]. Cloned primary trophozoites could produce populations switching between different VSPs [33] and some trophozoites lacked completely the surface coat [34].

Cell markers such as VSP are genes and their specific protein products are the molecular signature characterizing the stem cell populations [35]. In Giardia TSA417 is a dominant VSP surface antigen present in proliferative and dormant cell stages (trophozoites and innercyst cells) and a good marker for cell differentiation. During metacystic dedifferentiation 
Vladimir F. Niculescu, Stem Cell Biology and Research 2014,

(ex-cystment) TSA417 expression is repressed [36]. Transient metacystic cells (A1/8N and A2/4N) substitute TSA417 by a VSP-3EX stage-specific antigen (SSA-3EX). After conversion to PDP precursors, SSA-3EX is downregulated and the primary $P$ cells population predominantly expresses VSP-1EX for the next 5-6 days (Table 2).

Table 2. Differentiation marker and stage specific VSP antigens switching during Giardia's ex-cystment (metacystic phase).

\begin{tabular}{lllll}
\hline Cell type & VSP & D1 cell & D2 cell & References \\
\hline Innercyst cell 16N & TSA $^{417+}$ & -- & -- & {$[12,13,33,34]$} \\
Excyzoite (metacyst) 16N & TSA $^{417+}$ & -- & -- & {$[12,13,33,34]$} \\
2x4N propagule (A1 cells) & TSA $^{417-}$ & -- & -- & {$[12,13,33,34]$} \\
$4 x 2 N$ propagule (A2 cells) & VSP-3EX & -- & -- & {$[12,13,33,34]$} \\
Primary 2N cells (P cells) & VSP-1EX & TSA $^{417-}$ & TSA $^{417-}$ & {$[33,34]$} \\
\hline
\end{tabular}

Similar ancestral mechanisms of antigenic switching are conserved in undifferentiated embryonic stem cells (ESC), embryonic carcinoma cells (ECC) and embryonic germ cells (EGC) that express all TRA-1-60 and the stage-specific embryonic antigen SSEA4 [35]. Upon differentiation, TRA-1-60 and SSEA4 expression levels decrease and SSEA1 expression increases on human embryonic stem cells over time. Stage-specific antigens (SSA) are fundamentally implicated in pluripotency maintenance. Fully reprogrammed human iPS cells show downregulation of differentiated cell markers and upregulation of expression of SSEA-4 and TR-1-60 like pluripotent markers [35].

Most primary clones studied in Giardia [37] were TSA417 negative (TSA ${ }^{417}$ ). According to Giardia researchers TSA417 negative populations re-expressed TSA417 in long term cultures (LT cultures) and retained it for longer time periods ( $\geq 1$ year). Unfortunately, there is no reliable information on the VSP dynamics when subculturing primary populations, especially concerning environmental cues that induced TSA417 re-expression. However, there is much evidence that the primary non-continuous TSA ${ }^{417-}$ cell line ( $p$-SRL) converts by subculturing into a continuous t-SRL cell line producing TSA $^{417+}$ cells $\left(\right.$ MAT $^{417+}$ ) capable for ITD encystment. TSA417 seems to be a MAT specific surface antigen, expressed only by reversibly differentiated $T$ cells. It persists in the mature innercyst cell after encystment and disappears after ex-cystment. It is unknown if the innercyst cell of ATD cysts (spontaneous encysted MAS cells) are also TSA417 positive or not.

\section{Encystment and ploidization}

There are some discrepancies concerning any given cell types capacity for induced terminal differentiation ITD. In Physarum [39], Hydra's I cells [40] and several mammalian cell types such as mammary stem cells [41], mouse B lymphocytes [42], differentiation can also be induced in the $\mathrm{G} 2$ or $\mathrm{S} / \mathrm{G} 2$ phase, however, all of these processes include a mitotic response to the stimulus acting in G2 [38]. Terminal differentiation of ectodermal epithelial stem cells in organisms as Hydra can occur in $\mathrm{G} 2$, without requiring mitosis or $\mathrm{S}$ phase [38].

In Giardia most researchers suggest that trophozoites enter the ITD encystment pathway from the G2/M (8N) phase undergoing after precyst commitment a single round of DNA replication without mitosis, but this conclusion is based on limited results that-when considering flow cytometry studies [43-45] -seemed to be not true. Bernander et al., [43] found in growing SAT subpopulations two DNA peaks and consider them as being the pre-replicative tetraploid and postreplicative octoploid cell fractions, namely G1 (4N) and G2/M $(8 \mathrm{~N})$. In contrast to the non encysting trophozoites fraction (NET fraction) of Sulemana [16] the tetraploid 4N/G1 fraction of Bernander et al., [43] containing about $35 \%$ of the population [43] is not refractory to ITD stimuli. $1 \mathrm{~h}$ after cell transfer to $\mathrm{CM} / \mathrm{BB} 10.0$ this $4 \mathrm{~N}$ fraction enters the commitment phase. $3 \mathrm{~h}$ later ( $\mathrm{t} 4)$, half of the $4 \mathrm{~N}$ fraction doubled the number of genome copies and migrate to $8 \mathrm{~N}$. About $5-10 \%$ cells at this time continue endoploidization to $16 \mathrm{~N}$ cells. Unfortunately, we don't learn if these $16 \mathrm{~N}$ cells are cysts, committed precysts or cells waiting at the TD checkpoint for precyst commitment. On the other hand, the $8 \mathrm{~N}$ (G2/M) DNA peak ( $65 \%$ cells) don't increase significantly between t0 and t4, and it is also unclear if these cells are committed or not. What happens between $\mathrm{t} 4$ and $\mathrm{t} 24$ is not shown. At $\mathrm{t} 24$ all cells belonging to the $16 \mathrm{~N}$-fraction are probably cysts. The authors [43] suggest that the dominant $65 \%$ fraction (G2/M cells) don't undergo cell division and switched directly to cysts. In other words, genome duplication from $8 \mathrm{~N}$ to $16 \mathrm{~N}$ would take place after commitment during precyst maturation to mature cyst [16].

It is generally accepted that encystation occurred in Giardia preferentially from $\mathrm{G} 2$ cells that exit the ordinary cell cycle at a restriction point (G2/G0 state) permitting cyst differentiation [44]. Encystment starting from G1 phase was considered atypical, because the $4 \mathrm{~N} / \mathrm{G} 1$ cells have not been observed reaching the stationary phase [43]. However, what happens with the $4 \mathrm{~N}$ fraction arrested at a G1 bifurcation point (BP) in a state of double potency, that permits encystment from G1? What is the reason for its disappearance in the stationary growth phase: cell cycle progress, replication and cell cycle arrest to a further $\mathrm{G} 2$ checkpoint or a process of cell line conversion?

\section{AnSC hierarchy}

An attentive analysis of population dynamics in primary cultures and subcultures allows one to recognize and identify the different stem cell lines and their hierarchy in homogenous and multi-lined populations. An arithmetic progression indicates asymmetric cell fate and mitotic arrest of D2 cells. In $E$. invadens the absence of "spontaneous" ATD cysts in cultures shows that s-SRL/ATD line is lacking and the population contains only a t-SRL line or both t-SRL and p-SRL lines. Cells encysting "spontaneously" belong in our experience to the secondary stem cell line s-SRL/ATD following P/S conver- 
sion $[5,6]$. At the moment it is too early to make a definitive statement on Giardia's lineage hierarchy so long as we lack any details concerning cell line interconversion. Further, it is not clear whether Giardia's primary cell line p-SRL, is a noncontinuous pluripotent cell line that ends with the first passage to subculture $(\mathrm{Sc} 1)$, or later when adequate environmental conditions stop $\mathrm{p}$-SRL proliferation inducing conversion and potency restriction. However we do hypothesize that $\mathrm{P} / \mathrm{S}$ and $\mathrm{S} / \mathrm{T}$ conversion exist.

\section{$S$ cells and the s-SRL line}

We found evidence for multi-lined Giardia populations containing dominant mitotic arrested subpopulations, together with a minor fraction of "spontaneous encysting" ATD cells, indicating the coexistence of secondary and tertiary stem cell lines in culture. Similar situations occurred in LT cultures of E. invadens, that contain a minor s-SRL/ATD cell line named TD6 $^{\mathrm{LT}}$ besides the dominant t-SRL (ITD) line named QD24 ${ }^{\mathrm{LT}}$ [4]. We suspect in Giardia's axenic culture a minor s-SRL line (1-2\% of total population) is responsible for ATD cyst formation in the SAT population of Sulemana [16]. The minor subpopulation probably contains a cycling SRS cell fraction (D1 cells) which proliferates by asymmetric division producing MAS cells ( $\mathrm{D} 2$ cells) that encyst autonomously by ATD encystment. Autonomously occurring cysts substantiate our hypothesis predicting the existence of multi-lined populations in Giardia axenic cultures.

\section{$T$ cells and the $t-S R L$ line}

Sulemana [16] found in surface adhering SAT populations of Giardia's WB strain in fact a t-SRL cell line. It consists of mitotically determined SRT cells (D1 cells), refractory for ITD encystment. The author calls these cells non-encysting trophozoites (NET cells), in contrast to encysting trophozoites (ET cells) responding to ITD stimuli. NET cells produce mitotically arrested ET cells that are in fact MAT cells (D2 cells) capable of precyst commitment and ITD encystment. In the middle and stationary phases the ratio SRT: MAT $\left(\mathrm{D} 1^{\mathrm{IDD}}: \mathrm{D} 2^{\mathrm{ITD}+}\right)$ is $>1$. This $\mathrm{t}$-SRL cell line seems to be related to other t-SRL -like lines found by Meng et al., [36] in RB and C6 cultures that contain $75 \%$ to $85 \%$ TSA 417 expressing cells and $15 \%$ till $25 \%$ non expressing cells. We propose the minor fraction consists of cycling SRT ${ }^{417-}$ cells (D1 cells) and the major fraction consisting of reversible differentiated MAT ${ }^{417+}$ cells (D2 cells) capable for
ITD encystment (Table 3). There are no data indicating if the SRT417- cell fractions may encyst by ITD [36]. According to the authors there are no differences between surface adhering SAT subpopulations and non-adhering NAT subpopulations. The ratio $\mathrm{D} 1^{417-:} \mathrm{D} 2^{417+}$ is the same.

Some authors described the cell fraction dynamics in culture. Pimenta et al., [34] found 20\% TSA417 negative cells and $80 \%$ TSA417 positive cells (ratio 1:4). In other reports the ratio varies from $1: 3(75 \%)$ and $1: 4(80 \%)$ to about $1: 7(84 \%)$ and 1:9 $(89 \%)[16,36]$. This is strong evidence that populations with renewed expression of TSA417 contain a t-SRL stem cell line consisting of self renewal SRT ${ }^{417-c e l l s ~(D 1 ~ c e l l s) ~ t h a t ~}$ produces differentiated MAT417+ cells (D2 cells) capable for ITD encystment. The number of SRT ${ }^{417-}$ cells is constant from generation to generation. By subsequent asymmetric divisions the ratio $S R T^{417-}: \mathrm{MAT}^{417+}$ (D1:D2) increases, with the stem cell

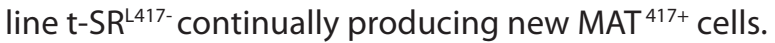

\section{VSP switching}

Indirect evidence for $\mathrm{P} / \mathrm{T}$ conversion and VSP switching was reported by Meng et al [36]. The authors assert that "upon prolonged subculture a variable tendency toward TSA417 reexpression" in negative clones is observed "immediately after ex-cystation". The predominant VSP then remains unchanged for month or years. We consider these findings as evidence for $\mathrm{P} / \mathrm{T}$ like conversion and antigenic switching from a primary population expressing VSP-1EX to a subsidiary TSA417 expressing population containing $\mathrm{MAT}^{417+}$ cells. In other words $\mathrm{P} / \mathrm{T}$ conversion in Giardia seemed to be accompanied by VSP-1EX downregulation and TSA417 upregulation, suggesting that specific antigenic changes follow signaling transduction and down regulation of genes. We propose that TSA417 as a specific differentiation marker for MAT ${ }^{417+}$ cells.

\section{The previous theory of VSP switching}

In the past the current opinion was that VSP switching occurred in individual cells by an intrinsic genetically determined mechanism. 20 years ago, the frequency of VSP switching respectively the rate of antigenic variation was estimated in WB-C9-6E7R clones that almost entirely lacked defined epitopes [46]. For studying VSP re-expression, cloned populations were transferred 6 days after start from the microtiterwells into $9 \mathrm{ml}$ culture tubes containing $8 \mathrm{ml}$ of high medium and counted 48-72 $\mathrm{h}$ later. The authors assumed that epitope

Table 3. Evidence on asymmetric cell fate and a multi- lined stem cell system in Giardia lamblia.

\begin{tabular}{llllllll}
\hline Cell type & $\begin{array}{l}\text { Presumtive } \\
\text { cell line }\end{array}$ & $\begin{array}{l}\text { Presumtive } \\
\text { conversion }\end{array}$ & D1 cells & D2 cells & D1-VSP & D2-VSP & References \\
\hline $\mathrm{P}$ & $\mathrm{p}-\mathrm{SRL}$ & $\mathrm{A} / \mathrm{P}$ & $\mathrm{SRP}$ & $\mathrm{MAP}$ & $\mathrm{TSA}^{417-}$ & TSA $^{417-}$ & {$[\mathbf{3 3 , 3 4}]$} \\
$\mathrm{S}$ & $\mathrm{s}-\mathrm{SRL}$ & $\mathrm{P} / \mathrm{S}$ & $\mathrm{SRS}$ & MAS & TSA $^{417-}$ & TSA $^{417+}$ & {$[\mathbf{1 4 , 4 7 , 5 2 , 5 4}]$} \\
$\mathrm{T}$ & $\mathrm{t}-\mathrm{SRL}$ & $\mathrm{P} / \mathrm{T}$ & $\mathrm{SRT}$ & MAT & TSA $^{\text {ITD- }}$ & TSA $^{\text {ITD+ }}$ & {$[\mathbf{1 4 , 3 3 , 3 4 , 4 4 - 4 6}]$} \\
\hline
\end{tabular}

The presumptive s-SRL cell line was identified by the few "spontaneous" cysts produced in the axenic culture.

Axenic cultures are less adequate for P/S conversion and ATD excystment. 
re-expression is a unique mutation-like event occurring after 12 symmetric divisions in a single cell of the $13^{\text {th }}$ logarithmical cell generation (switching frequency). Following the same assumptions the authors referred to a GS/M-H7 clone studied in parallel and considered VSP switching as a single cell event occurring in the $6^{\text {th }} / 7^{\text {th }}$ generation $[46,47]$. According to the authors the cell density of the clone WB-C9-6E7R must be at the switching time in the range of $2^{12}$ cells and the switching ratio must be $n \times 10^{-3}\left(1: 10^{3}\right)[48]$.

The data supporting this assumption are lacking. All clones were simultaneously checked by immunological assays and counted 48 or $72 \mathrm{~h}$ after transfer into culture tubes, however previous evaluation results between cloning and counting were not reported. Thus, it is unknown how cloned populations evolved between cloning and counting, how many cells are actually needed to start proliferation of the metabolic anaerobe Giardia cells in oxygen rich microtiter wells (possibly more than one) or how the serial microdilution stressed cells oxidatively. It is unknown whether clones transferred to the culture tubes contained homologous cells or non-identical cell fractions, if VSP switching occurred before or during the cell transfer, or if transferred cells re-expressed even parental VSP and at what percentage.

We supposed that Giardia cells were repeatedly exposed in these experiments to oxidative stress and other environmental stimuli (stress by cloning, microtiter dilution, passaging to culture tubes) that induce cell conversion. After passaging cells grew at first in more oxygenic conditions, however, hypoxia increased more and more, because Giardia consumed themselves the dissolved oxygen from the culture medium which lacked any source replenishing the $\mathrm{O}_{2}$ [49-51]. New passages mean new oxidative stress. In E. invadens oxidative stress by passaging followed by different ranges of hypoxia met in OCB sediments assured $\mathrm{P} / \mathrm{S}$ and $\mathrm{P} / \mathrm{T}$ conversion. It is difficult to understand why cell conversion and antigen switching affects only a few cells of the WB-C9-6E7R clone. Conversion occurred probably at a time when the clone becomes heterogeneous, containing cells of distinct cell type. One a minor cell fraction becomes permissive for cell conversion and a major cell fraction becomes refractory for conversion, as observed in E. invadens. Short-term conversion stimuli and a limited cell cycle window would be also conceivable. These questions need to be further clarified.

\section{VSP as stem cell differentiation marker}

Already Gilman et al., [52] suspected antigen coating as an indicator of cell differentiation, but this assumption was not further investigated. Numerous molecular biological studies of VSP followed, but the understanding of the vegetative cell biology of Giardia did not move forward. Nothing is known about the effects of oxidative and strong hypoxic stress in super-dense Giardia populations or the specific effects of passaging. Signaling mechanisms for growth and cell line conversion were not understood. It is also unclear whether a single anaerobic Giardia cell (cloned cell by microtitration) can really start proliferation in axenic cultures containing about $6.7 \mathrm{mg} \mathrm{DO}$ (dissolved $\mathrm{O}_{2} / \mathrm{l}$ at $37^{\circ} \mathrm{C}$ ) or if more cells are needed to consume oxygen and improve proliferation conditions. Similar to the metabolic anaerobe E. invadens, Giardia needs probable lower pO2 values (light hypoxia) to start proliferation but favorable $\mathrm{pO} 2$ values can be achieved only by OCB associates or by sufficient amounts of low oxygen consuming Giardia cells [49-51].

In the last years more and more researchers suggest that antigenic switching may occur during cell division events linked with the ex-cystment process [21,53]. Pruca et al., [54] even believe "it is possible that during cell division each daughter switches to the expression of a different VSP, as occurs in higher eukaryotes" and in fact were nearly correct. This supposition sustained the stem cell biological point of view. Accordingly, the driving motor of the TSA417 positive population is a TSA417 negative stem cell line t-SRL ${ }^{417}$. It consists of cycling $\mathrm{SRT}^{417-}$ (D1 cells) that divide asymmetrically giving rise to non-identical daughter cells. One is the new self renewing $\mathrm{SRT}^{417-}$ cell (D1 cell) and the other the $\mathrm{MAT}^{417+}$ cell (D2 cell) capable for ITD encystment.

\section{T cells capacity for ITD encystment}

The NET/ET population described by Sulemana [16] is in our opinion a SRT ITD -:MAT ${ }^{\text {TID + }}$ population. The data of Sulemana refer to a SAT cell fraction of about 60\% harvested from 24-72 h old Giardia cultures grown in TYI-S-33 media enriched with $1.0 \mathrm{mg} / \mathrm{ml}$ bovine bile or not (CM/WBB, CM/BB1.0) $[55,56]$ and then transferred for ITD encystment in $10 \mathrm{mg} / \mathrm{ml}$ bovine bile medium (CM/BB10). $24 \mathrm{~h}$ after inoculation in CM/WBB growth medium (t24) the ratio NET:ET was 25:75. This result can be achieved only by asymmetric divisions $(n=3)$ and expressed a $D 1^{3}: D 2^{1-3}$ ratio. $D 1^{3}$ cells are SRT cells in the $3^{\text {rd }}$ generation and $\mathrm{D} 2^{1-3}$ are MAT cells from three cell generations. By prolonged cultivation (t24-t72) the MA fraction increased to $80 \%$ (t48/ $n=4)$, respectively $83-85 \%(t 72 / n=5)$. Evidently, the population did not grow logarithmically. The t-SRL cell line of Giardia is strongly related to the tertiary t-SRL line from $E$. invadens.

\section{Cycling SRT ${ }^{\text {ITD- }}$ cells}

The driving motor of the SAT subpopulation is the t-SRL line consisting of SRT ITD - cells that proliferate by asymmetric divisions, giving rise to non identical daughter cells (SRT ${ }^{\text {TD - }}$ and $\mathrm{MAT}^{\mathrm{ITD}+}$ cells). The average generation time was of about $8 \mathrm{~h}$ (AGT8). Other authors reported AGT values between 6.5 and $14 \mathrm{~h}$ [57]. After cell division, D1 cells (SRT, ET) become mitotically determined and continue to progress through the cell cycle. Independent of whether the cells were transferred in "pre-encysting" CM/WBB or in "encysting" CM/BB10.0 medium, SRT ITD - cells continue to proliferate asymmetrically, giving rise to new SRT ITD - and MAT ITD+ daughter cells.

In contrast to the MAT ${ }^{\mathrm{ITD}+}$ cell fraction, that decides in CM/ BB10.0 for precyst commitment, SRT ${ }^{\text {ITD }}$ - cells chose for self- 
renewal and mitotic determination. For some unknown reason, they don't perceive the ITD effect of bovine bile present in the CM/BB10.0 culture. We assume that mitotic stimuli, such as bovine serum and other vegetative growth factors, act quickly and D1 cells end the state of double potency and become mitotically determined as SRT ${ }^{\mathrm{ITD}}$ - cells, even before bovine bile may initiate commitment.

\section{Quiescent MAT ${ }^{I T D+}$ cells}

$\mathrm{MAT}^{\mathrm{TD}+}$ cells remain quiescent waiting for further decisions. They are reversible differentiated cells in G0 state. When passaged in normal culture medium-without or reduced concentrations of bovine bile (CM/WBB)-they re-enter the cell cycle, thus, replenishing the self-renewing stem cell line t-SRL. In CM/BB10.0 encystment medium MAT ${ }^{1 \mathrm{TD}}+$ cells were committed to precysts, apparently without further cell division.

MAT cells have in both protists (Giardia and E. invadens) the following perspectives: (i) in conditions optimal for quiescence they remain for longer periods mitoticly arrested, (ii) by passaging in subculture they re-enter the cell cycle, replenishing the stem cell line and (iii) encountering appropriate ITD stimuli they enter commitment and encyst after passing the point of no return (bifurcation point). In Giardia the precyst commitment phase takes place after about 6-12 h [16]. Committed cells (precysts) are irreversibly determined for terminal differentiation and encyst, even when transferred in CM/WBB media without bovine bile. Non-committed MAT cells are blocked at the bifurcation checkpoint and may re-enter cell cycle for further proliferation. The question is what is the ultimate difference between quiescent MAT cells before and after commitment? We shall explore this question in relation to vegetative ploidy and ITD ploidization.

\section{ATD encystment}

We hypothesized that the minor fraction of "spontaneous" cysts observed in SAT subpopulations $[16,60]$ is produced by a secondary s-SRL cell line similar with the s-SRL/ATD stem cell line of $E$. invadens, that encysts by intrinsic mechanisms for autonomous terminal differentiation $[3,5,6]$. However, axenic growth conditions do not promote the development of a dominant s-SRL cell line for mass encystment.

In E. invadens' LT cultures, "spontaneous" cyst production is performed by a minor s-SRL/ATD line of 1-3\% [5]. In OCB cultures, mass encystment occurred both in primary cultures and subcultures $(\mathrm{Sc})$ by a dominant s-SRL stem cell line started from primary $P$ cells [6]. $P / S$ conversion is induced by oxidative stimuli. Passaging primary $P$ cells in the first passage $(\mathrm{SC} 1)$ both SRP and MAP cells convert to PDS predecessors for the $s$-SRL. PDS cells divide asymmetrically to SRS and MAS cells (D1 and D2 cells) and MAS cells differentiate autonomously to ATD cysts. In our experience four MAS cell generations (D2 ${ }^{1-4}$ cells) encysted in the first 28-30 $\mathrm{h}$ after inoculation. Thus, the $S$ cell population contain $80 \%$ ATD cysts and $20 \%$ cycling SRS stem cells. Hypoxic changes occurring at the end of the early growth phase (t28/t30) convert secondary $\mathrm{D} 1{ }^{4}$ cells to a tertiary $\mathrm{t}-\mathrm{SRL}$ stem cell line by $\mathrm{S} / \mathrm{T}$ conversion. The population becomes multi-lined containing ATD cysts from the s-SRL and tertiary trophozoites from the continuous t-SRL. In the next passage $(\mathrm{Sc} 2)$, some ATD cysts hatched to produce a new p-SRL line. The oxidative stress by passaging to $\mathrm{Sc} 3$, converts the multilined $\mathrm{P}+\mathrm{T}$ population into $\mathrm{S}+\mathrm{T}$ population. The young s-SRL line produces the next generation of ATD cysts, which can hatched out in Sc4. Thus, the non-continuous s-SRL is again restored, regenerating in LT cultures from young primary $\mathrm{P}$ cells transferred in subcultures.

\section{$4 \mathrm{~N}$ and $8 \mathrm{~N}$ cell fractions}

Several authors described in logarithmic growing SAT subpopulations, two cycling cell fractions which differ significantly with one another [43-45]. One of them is the minor $4 \mathrm{~N}$ fraction of about $20 \%$ and the other the major $8 \mathrm{~N}$ fraction of about $80 \%$ (ratio 1:5). In contrast to the t-SRL line consisting of SRT ITD - cells, each of the both $4 \mathrm{~N}$ and $8 \mathrm{~N}$ cycling cell fractions consist of identical cells and may be induced for ITD encystment. The interrelations between both fractions are unclear.

Our particular focus was the minor $4 \mathrm{~N}$ cell fraction regarded in the last as less significant for ITD encystment. On closer examination it can be observed, that both $4 \mathrm{~N}^{1 \mathrm{TD}+}$ and $8 \mathrm{~N}^{1 \mathrm{TD}+}$ cell fractions arrest postmitotically in a state of double potency, waiting for the definitive decision: either ITD encystment or mitotic proliferation. Specific stimuli decide the cells fate. Sixty minutes after transfer to CM/BB10.0 and ITD induction, a $18 \mathrm{~h}$ old $4 \mathrm{~N}$ cell fraction $(2 \times 2 \mathrm{~N})$ begins to replicate genome copies needed for precyst commitment. 3h later ( $\mathrm{t} 4)$ the majority of the previously 4N/G1 cells had a ploidy of $8 \mathrm{~N}$ [43] having become commited to $4 \times 2 \mathrm{~N}$ precysts [44].

When the $18 \mathrm{~h}$ old control sample continue proliferation in normal growth conditions both cell fractions $4 \mathrm{~N}^{1 T D+}$ and $8 \mathrm{~N}^{1 \mathrm{TD}+}$ progress through the cell cycle simultaneously, divide symmetrically and arrest again in the state of double potency, so long as the needs for passaging the checkpoint are not met. The question is: Arrest $4 \mathrm{~N}$ cells postmitotically at the G1-checkpoint and $8 \mathrm{~N}$ cells at a G2-checkpoint, or consist both fractions of temporarily arrested $\mathrm{G} 1$ cells? Much speaks for the first option.

The minor $4 \mathrm{~N}^{\mathrm{ITD}+}$ cell fraction is certainly not a continuous cell line. It converts in the late growth phase into the major $8 \mathrm{~N}^{1 \mathrm{TD}+}$ cell line by changing environmental conditions ( $\mathrm{pO} 2$, hypoxia, etc) and does not appear in the flow cytometrical diagram [43-45]. We found no data clarifying whether stationary $8 \mathrm{~N}^{1 \mathrm{TD}+}$ inoculi regenerate the $4 \mathrm{~N}^{\mid T D+}$ fraction in subcultures. There are less data on its position in the lineage hierarchy or where they come from.

Another striking difference between both $4 \mathrm{~N}^{1 \mathrm{TD}+}$ and $8 \mathrm{~N}^{1 \mathrm{TD}+}$ cell fractions is their response to $\mathrm{G} 1$ blocker aphidicolin and G2 blocker nocodazole $[\mathbf{4 4 , 4 5 ]}$. Aphidicolin is a cell cycle inhibitor that blocks cell cycle at the early S-phase, however, it also blocks cell cycle progression and cell division [58] and 
is involved in the dissociation of replicative-mitotic events [59]. The best synchronization of the cell cycle was obtained with concentrations of $5 \mu \mathrm{g} \mathrm{ml}^{-1}$ aphidocolin, however, distinct differences between both $4 \mathrm{~N}^{1 \mathrm{TD}+}$ and $8 \mathrm{~N}^{\mathrm{IDD}+}$ cell fractions were detected using aphidicolin at $10 \mu \mathrm{g} \mathrm{ml}^{-1}$. At this concentration aphidicolin arrests cell division of the previously $4 \mathrm{~N}^{1 \mathrm{TD}+} / \mathrm{G} 1 \mathrm{frac}-$ tion in a $8 \mathrm{~N}$ - ploid $\mathrm{G} 2 / \mathrm{M}$ state, while the $8 \mathrm{~N}^{\mathrm{ID}+}$ line continue cell division normally. These data show that in contrast to $4 \mathrm{~N}^{1 \mathrm{TD}+}$ cells the $8 \mathrm{~N}^{1 \mathrm{TD}+}$ line arrests in culture temporarily at a G2 checkpoint and both cell fractions have different molecular mechanisms of cell cycle progression.

\section{Multilined Giardia cultures}

According to conventional wisdom, Giardia cysts should not be able to hatch in growth medium. They need a low gastric $\mathrm{pH}$ as the initial trigger, in order to activate cysteine proteases, which degrade the cyst wall from the inside [60]. The definitive evidence clarifying whether Giardia ATD cysts can hatch or not hatch under any specific circumstances in growth medium does not exist. Thus, we cannot exclude the possibility that some young cysts excyst in culture, giving rise to a minor primary stem cell line $\mathrm{p}-\mathrm{SRL}$ giving rise to SRP and MAP cells. The low hypoxic stimuli necessary for $\mathrm{P}$ cell conversion ( $\mathrm{P} / \mathrm{S}$ and P/T) could be provided by Giardia trophozoites themselves. Giardia is a hypoxic eukaryote with anaerobic metabolism, endowed with oxygen consuming mechanisms $[\mathbf{5 0 , 5 1 ]}$. It is able to consume dissolved oxygen at low levels (0 to $50 \mu \mathrm{M})$ for scavenging toxic $\mathrm{O}_{2}$ effects [49]. Similar $\mathrm{O}_{2}$ concentrations $(\leq 60 \mu \mathrm{M})$ exist in Giardia's natural habitat, the upper intestine. The apparent oxygen affinities in Giardia range from 0.5 to 5.2 $\mu \mathrm{M}$ [51]. P/S conversion probably occurred in the first half of the logarithmic growth phase $(\leq t-48)$, before the population increases to $10^{5}$ trophozoites $/ \mathrm{ml}$ [61].

In Giardia there are some information about "spontaneously" cysts, produced by the WB strain/clone C6 in modified TYI-S-33 medium $[16,55,62]$. The majority of cells proliferate with an average generation time of about $7 \mathrm{~h}$ (AGT7). The number of "spontaneous" cysts produced in the late growth phase (t72 t96) increased from 0 units $/ \mathrm{ml}$ in the middle growth phase (t48) to approximately 500 cysts $/ \mathrm{ml}$ (t-72) and 1000 cysts $/ \mathrm{ml}$ (t-96) respectively 0 to $0.05 \%$ and $0.1 \%$ [62]. This data could indicate an asymmetric dividing s-SRL with an AGT $\leq 24$ capable of autonomous terminal differentiation ATD. However there are too few cysts for accurate conclusions. Sulemana [16] reported $10 \%$ spontaneous encystment in a $72 \mathrm{~h}$ old population, however, no data concerning encystment dynamics in culture were presented. In the case of $E$. invadens' $L T$ cultures ATD encystment occurs in the oxidative growth phase (t0-t72).

\section{Conclusions}

In preparing this work, the most significant literature of the past 25 years has been examined. It is clear that today's knowledge of the cell biology of Giardia is limited. Most stimuli which may control the vegetative life cycle of this protist pathogen in culture ( $\mathrm{pO} 2$, hypoxia, hypoxia dynamics, oxidative and strong hypoxic stress) has not been considered and are not understood in Giardia. Their effects are as good as unknown. The missing data necessary to fill this gap are continuous monitoring of the population kinetics in primary cultures, subcultures and long term cultures. It is not known under what conditions proliferation and cell division is symmetric or asymmetric, and the circumstances under which a population of non-identical cell fate switches to the identical cell fate program.

Undoubtedly, Giardia has a variety of distinct differentiated cell types, yet the cell lineage hierarchy is unexplained. Reviewing Giardia studies from the last 25 years in light of what is known about the E. invadens stem cell biology, we can detect evidence for undetermined cells in a state of double potency, waiting as reversible differentiated cells for induced terminal differentiation or cell cycle progress (as MAT cells) and cells outside the state of double potency, that are mitotically determined for self renewing and not able for ITD encystment (SRT TD- cells). Both the $\mathrm{p}$-SRL line lacking TSA417 and the t-SRL line which expresses TSA417 were able to establish themselves well in the axenic culture conditions. We also suggest the existence of a genuine secondary s-SRL line capable of ATD encystment, which can develop under the minimalist conditions of axenic culture. This cell line needs to be examined in more detail under altered $\mathrm{pO} 2$ or controlled OCB conditions.

Regarding the cell line hierarchy, the conversion capacity and the vegetative life duration of each cell lines, they need to be clarified by subsequent studies. We propose the p-SRL as a non-continuous cell line in contrast to the continuous t-SRL line, surviving infinitely in optimal growth conditions. It also remains to be determined what is the hierarchical position of the non-continuous proliferating cell fraction $4 \mathrm{~N}^{\mathrm{ITD}+}$ and how it relates to the $8 \mathrm{~N}^{1 \mathrm{TD}+}$ line. Further, if these cell fractions proliferate symmetrical or asymmetrical. These outstanding issues should be resolved.

Undoubtedly, differentiation in Giardia is not reduced to encystment and ex-cystment. Encystment is a process of terminal differentiation to the pluripotent $16 \mathrm{~N}$ innercyst cell. Ex-cystment is rather a process of de-differentiation and return to proliferating undifferentiated stem cell lines. Cell differentiation in Giardia includes cell line conversion reversible differentiation and mitotic arrest. Terminal differentiation takes place by induced (extrinsic) and autonomous (intrinsic) mechanisms. It is unclear if ITD and ATD cysts are identical; cells producing them are clearly distinct, and they reside in different cell populations. The best marker to identify the different stem cell lines is certainly their capacity to encyst by ITD or ATD. VSP dynamics within Giardia's lineage are intriguing. TSA417 switching is evolutionarily determined, and can be a marker of great interest. The antigen switching frequency with each $6^{\text {th }} / 13^{\text {th }}$ cell generation is a critical branch point and must be confirmed. There is a strong suspicion, that VSP 
switching and cell line conversion could be triggered by culture passages, oxygenic stress and fresh culture medium. Little is known about the genomic and protein sequence homology between such an antigen and those of other stem cells.

Antigenic switching is not the unique indicator of a real protist stem cell system. The most significant evidence is the asymmetric cell fate with self renewing and mitotically arrested cells (D1 and D2 cell fractions), the capacity of MAP and MAT cells to re-enter cell cycle for replenishing the current SRL line and the capacity of MAT and MAS cells to differentiate terminally by induced or autonomous molecular mechanisms.

\section{List of abbreviations}

OCB: Oxygen consuming bacteria (OCB niches)

AnSC: Ancient stem cells

LECA: Last eukaryotic common ancestor

pO2: Oxygen pressure

D1 and D2 cells: Non identical daughter cells

$\mathrm{SRL}$ : Self renewing stem cell lines ( $p$-SRL, s-SRL, t-SRL)

A1, A2: Metacystic propagule (amoebulae)

PDP: Predecesor cell for primary stem cells

$\mathrm{P}, \mathrm{S}, \mathrm{T}$ : Primary, secondary and tertiary stem cells

SRC: Self renewing stem cells (cycling D1 cells)

SRP, SRS, SRT: Primary, secondary and tertiary self renewing cells MA: Mitotic arrested stem cells (quiescent D2)

MAP, MAS, MAT: Primary, secondary and tertiary MA cells

TD: Terminal differentiation

ITD: Induced terminal differentiation

ATD: Autonomous terminal differentiation

s-SRL/ATD: Secondary stem cell line producing ATD cysts

t-SRL(ITD): Tertiary stem cell line capable of ITD

AGT: Average generation time

CM/WBB: Culture media without bovine bile

CM/BB10.0, CM/BB1.0: Culture media with bovine bile

4C, 8C: Four/eight genome copies

$4 \mathrm{~N}$ : Tetraploid cells (G1 cells)

$8 \mathrm{~N}$ : Octoploid cells (G2/M cells)

RP: G1 restriction point

BP: Point of cell fate bifurcation

ET: Encysting trophozoite

NET: Non-encysting trophozoite

TSA417: Trophozoite surface antigen

VSP: Variable surface proteins

SAT: Surface adhering trophozoites

NAT: Non-adhering trophozoite

\section{Competing interests}

The author declares that he has no competing interests.

\section{Aknowledgement}

The author expresses his gratitude to Dr. Dennis Thomas (native english speaker) for reading of the manuscript and excellent support.

\section{Publication history}

Editor: Prasad S Koka, Haffkine Institute for Training, Research and Testing, India.

Received: 16-May-2014 Final Revised: 10-Oct-2014

Accepted: 27-Oct-2014 Published: 03-Nov-2014

\section{References}

1. Ramalho-Santos $\mathrm{M}$ and Willenbring $\mathrm{H}$. On the origin of the term "stem cell". Cell Stem Cell. 2007; 1:35-8. | Article | PubMed

2. Niculescu VF. On the origin of stemness and ancient cell lineages in single-celled eukaryotes. SOJ Microbiol Infect Dis. 2014; 2:1-3. | Article

3. Niculescu VF. The evolutionary history of eukaryotes: how the ancestral proto-lineage conserved in hypoxic eukaryotes led to protist pathogenicity. Microbiol Discov. 2014; 2:4. I Article

4. Niculescu VF. The primitive cell system of Entamoeba invadens. ICOPA III, Third Intern. Congress of Parasitology, section A11, München. 1974. I Pdf

5. Niculescu VF. Growth of Entamoeba invadens in sediments with metabolically repressed bacteria leads to multicellularity and redefinition of the amoebic cell system. Roum Arch Microbiol Immunol. 2013; 72:25-48. | PubMed

6. Niculescu VF. The stem cell biology of the pathogen protist Entamoeba invadens in the context of eukaryotic evolution. 2014.

7. Niculescu VF. A culture method for study of the cell system in Entamoeba invadens. ICOPA III, Third Intern. Congress of Parasitology, section G3, München. 1974. I Website

8. Martin-Rendon E and Watt SM. Stem cell plasticity. Br J Haematol. 2003; 122:877-91. | Article | PubMed

9. Quesenberry PJ, Abedi M, Aliotta J, Colvin G, Demers D, Dooner M, Greer D, Hebert H, Menon MK, Pimentel J and Paggioli D. Stem cell plasticity: an overview. Blood Cells Mol Dis. 2004; 32:1-4. | Article I PubMed

10. Lakshmipathy U and Verfaillie C. Stem cell plasticity. Blood Rev. 2005; 19:29-38. | Article | PubMed

11. Watanabe H, Hoang VT, Mattner R and Holstein TW. Immortality and the base of multicellular life: Lessons from cnidarian stem cells. Semin Cell Dev Biol. 2009; 20:1114-25. | Article | PubMed

12. Hernandez Y, Shpak M, Duarte TT, Mendez TL, Maldonado RA, Roychowdhury S, Rodrigues ML and Das S. Novel role of sphingolipid synthesis genes in regulating giardial encystation. Infect Immun. 2008; 76:2939-49. | Article | PubMed Abstract | PubMed Full text

13. Jonson $M$. Identification and characterization of immunmodulating proteins in Giardia lamblia. Upsala Universitet. 2008. I Pdf

14. Feely DE, Gardner MD and Hardin EL. Excystation of Giardia muris induced by a phosphate-bicarbonate medium: localization of acid phosphatase. J Parasitol. 1991; 77:441-8. | Article | PubMed

15. Adam RD. The Giardia lamblia genome. Int J Parasitol. 2001; 30:475-484. I Article

16. Sulemana A. Bistability in the protozoan parasite Giardia lamblia. Biology Dissertation. Northeastern University. 2011. | Article

17. Sommerville J. Serotype expression in Paramecium. Adv Microb Physiol. 1970; 4:131-178.

18. Caron $\mathrm{F}$ and Meyer $\mathrm{E}$. Molecular basis of surface antigen variation in paramecia. Annu Rev Microbiol. 1989; 43:23-42 | Article | PubMed

19. Deitsch KW, Lukehart SA and Stringer JR. Common strategies for antigenic variation by bacterial, fungal and protozoan pathogens. Nat Rev Microbiol. 2009; 7:493-503. | Article | PubMed Abstract | PubMed Full text

20. Allen SI and Gibson I. Genetics of Tetrahymena. In: Biology of Tetrahymena (ed Elliot AM). New York: Van Nostrand Reinhold. 2011; 307-373.

21. Prucca CG, Rivero FD and Lujan HD. Regulation of antigenic variation in Giardia lamblia. Annu Rev Microbiol. 2011; 65:611-30. | Article | PubMed

22. Devera R, Fernandes $O$ and Coura JR. Should Trypanosoma cruzi be called "cruzi" complex? a review of the parasite diversity and the potential of selecting population after in vitro culturing and mice infection. Mem Inst Oswaldo Cruz. 2003; 98:1-12. | Article | PubMed

23. Bartholomeu DC, Cerqueira GC, Leao AC, daRocha WD, Pais FS, Macedo C, Djikeng A, Teixeira SM and El-Sayed NM. Genomic organization and expression profile of the mucin-associated surface protein (masp) family of the human pathogen Trypanosoma cruzi. Nucleic Acids Res. 2009; 37:3407-17 | Article | PubMed Abstract | PubMed Full text

24. Clayton JJ and Frasch AC. The procyclic surface protein of Trypanosoma 
brucei. In Wang CC (ed) Molecular and immunological aspects of parasitism. American Association of Advancement of Science Washington DC. 1991.

25. Rudenko G. Mechanisms mediating antigenic variation in Trypanosoma brucei. Mem Inst Oswaldo Cruz. 1999; 94:235-7 | Article I PubMed

26. Navarro M and Gull K. A pol I transcriptional body associated with VSG mono-allelic expression in Trypanosoma brucei. Nature. 2001; 414:75963. | Article | PubMed

27. Murray PJ and Spithill TW. Variants of a Leishmania surface antigen derived from a multigenic family. J Biol Chem. 1991; 266:24477-84. | Article I PubMed

28. Anders RF, McColl DJ and Coppel RL. Molecular variation in Plasmodium falciparum: polymorphic antigens of asexual erythrocytic stages. Acta Trop. 1993; 53:239-53. | Article | PubMed

29. Craig A and Scherf A. Molecules on the surface of the Plasmodium falciparum infected erythrocyte and their role in malaria pathogenesis and immune evasion. Mol Biochem Parasitol. 2001; 115:129-43. | Article I PubMed

30. Stanley SL, Jr., Becker A, Kunz-Jenkins C, Foster L and Li E. Cloning and expression of a membrane antigen of Entamoeba histolytica possessing multiple tandem repeats. Proc Natl Acad Sci U S A. 1990; 87:4976-80. Article | PubMed Abstract | PubMed Full text

31. Bienz M, Siles-Lucas M, Wittwer $P$ and Muller N. vsp gene expression by Giardia lamblia clone GS/M-83-H7 during antigenic variation in vivo and in vitro. Infect Immun. 2001; 69:5278-85. | Article | PubMed Abstract | PubMed Full text

32. Nash T. Surface antigen variability and variation in Giardia lamblia. Parasitol Today. 1992; 8:229-34. | Article | PubMed

33. Nash TE, Aggarwal A, Adam RD, Conrad JT and Merritt JW, Jr. Antigenic variation in Giardia lamblia. J Immunol. 1988; 141:636-41. | Article | PubMed

34. Pimenta PF, da Silva PP and Nash T. Variant surface antigens of Giardia lamblia are associated with the presence of a thick cell coat: thin section and label fracture immunocytochemistry survey. Infect Immun. 1991; 59:3989-96. | Article | PubMed Abstract | PubMed Full text

35. Pazhanisamy S. Adult stem cell and embryonic stem cell markers. Labome. 2013. I Article

36. Meng TC, Hetsko ML and Gillin FD. Antigenic switching of TSA 417, a trophozoite variable surface protein, following completion of the life cycle of Giardia lamblia. Infect Immun. 1993; 61:5394-7. | Article | PubMed Abstract | PubMed Full text

37. Svard SG, Meng TC, Hetsko ML, McCaffery JM and Gillin FD. Differentiation-associated surface antigen variation in the ancient eukaryote Giardia lamblia. Mol Microbiol. 1998; 30:979-89. | Article PubMed

38. Dubel $\mathrm{S}$ and Schaller HC. Terminal differentiation of ectodermal epithelial stem cells of Hydra can occur in $\mathrm{G} 2$ without requiring mitosis or S phase. J Cell Biol. 1990; 110:939-45. | Article | PubMed Abstract | PubMed Full text

39. Nobori T and Nishi A. Differentiation response of Physarum polycephalum to macrocysts at various times in nuclear cycle. Exp Cell Res. 1984; 152:436-42. | Article | PubMed

40. Hoffmeister SAH and Schaller HC. Head activator and head inhibitor are signals for nerve cell differentiation in Hydra. Dev Biol. 1987; 122:72-77. | Article

41. Smith GH and Medina D. A morphologically distinct candidate for an epithelial stem cell in mouse mammary gland. J Cell Sci. 1988; 90:17383. | Article | PubMed

42. Melchers $\mathrm{F}$ and Lernhardt $\mathrm{W}$. Three restriction points in the cell cycle of activated murine B lymphocytes. Proc Natl Acad Sci U S A. 1985; 82:7681-5 | Article | PubMed Abstract | PubMed Full text

43. Bernander R, Palm JE and Svard SG. Genome ploidy in different stages of the Giardia lamblia life cycle. Cell Microbiol. 2001; 3:55-62. | Article | PubMed

44. Reiner DS, Ankarklev J, Troell K, Palm D, Bernander R, Gillin FD, Andersson JO and Svard SG. Synchronisation of Giardia lamblia: identification of cell cycle stage-specific genes and a differentiation restriction point. Int
J Parasitol. 2008; 38:935-44. | Article | PubMed

45. Poxleitner MK, Dawson SC and Cande WZ. Cell cycle synchrony in Giardia intestinalis cultures achieved by using nocodazole and aphidicolin. Eukaryot Cell. 2008; 7:569-74. | Article | PubMed Abstract | PubMed Full text

46. Nash TE, Banks SM, Alling DW, Merritt JW, Jr. and Conrad JT. Frequency of variant antigens in Giardia lamblia. Exp Parasitol. 1990; 71:415-21. | Article I PubMed

47. Zhang YY, Aley SB, Stanley SL, Jr. and Gillin FD. Cysteine-dependent zinc binding by membrane proteins of Giardia lamblia. Infect Immun. 1993; 61:520-4. | Article | PubMed Abstract | PubMed Full text

48. Kulakova L, Singer SM, Conrad J and Nash TE. Epigenetic mechanisms are involved in the control of Giardia lamblia antigenic variation. $\mathrm{Mol}$ Microbiol. 2006; 61:1533-42. | Article | PubMed

49. Lloyd D, Harris JC, Maroulis S, Biagini GA, Wadley RB, Turner MP and Edwards MR. The microaerophilic flagellate Giardia intestinalis: oxygen and its reaction products collapse membrane potential and cause cytotoxicity. Microbiology. 2000; 146:3109-18. I Article I PubMed

50. Di Matteo A, Scandurra FM, Testa F, Forte E, Sarti P, Brunori M and Giuffre A. The O2-scavenging flavodiiron protein in the human parasite Giardia intestinalis. J Biol Chem. 2008; 283:4061-8. | Article | PubMed

51. Mastronicola D, Giuffre A, Testa F, Mura A, Forte E, Bordi E, Pucillo LP, Fiori PL and Sarti P. Giardia intestinalis escapes oxidative stress by colonizing the small intestine: A molecular hypothesis. IUBMB Life. 2011; 63:21-5. | Article | PubMed

52. Gilman RH, Marquis GS, Miranda E, Vestegui M and Martinez H. Rapid reinfection by Giardia lamblia after treatment in a hyperendemic Third World community. Lancet. 1988; 1:343-5. | Article | PubMed

53. Adam RD. Biology of Giardia lamblia. Clin Microbiol Rev. 2001; 14:44775. | Article | PubMed Abstract | PubMed Full text

54. Prucca CG and Lujan HD. Antigenic variation in Giardia lamblia. Cell Microbiol. 2009; 11:1706-15. | Article | PubMed

55. Keister DB. Axenic culture of Giardia lamblia in TYI-S-33 medium supplemented with bile. Trans R Soc Trop Med Hyg. 1983; 77:487-8. | Article I PubMed

56. Kane AV, Ward HD, Keusch GT and Pereira ME. In vitro encystation of Giardia lamblia: large-scale production of in vitro cysts and strain and clone differences in encystation efficiency. J Parasitol. 1991; 77:974-81. I PubMed

57. Gourguechon S, Holt LJ and Cande WZ. The Giardia cell cycle progresses independently of the anaphase-promoting complex. J Cell Sci. 2013; 126:2246-55. | Article | PubMed Abstract | PubMed Full text

58. Butler SL, Johnson EP and Bushman FD. Human immunodeficiency virus cDNA metabolism: notable stability of two-long terminal repeat circles. J Virol. 2002; 76:3739-47. | Article | PubMed Abstract | PubMed Full text

59. Kung AL, Zetterberg A, Sherwood SW and Schimke RT. Cytotoxic effects of cell cycle phase specific agents: result of cell cycle perturbation. Cancer Res. 1990; 50:7307-17. | Article | PubMed

60. Ward W, Alvarado L, Rawlings ND, Engel JC, Franklin C and McKerrow $\mathrm{JH}$. A primitive enzyme for a primitive cell: the protease required for excystation of Giardia. Cell. 1997; 89:437-44. | Article I PubMed

61. Ellis JE, Wingfield JM, Cole D, Boreham PF and Lloyd D. Oxygen affinities of metronidazole-resistant and -sensitive stocks of Giardia intestinalis. Int J Parasitol. 1993; 23:35-9. I Article I PubMed

62. Su LH, Lee GA, Huang YC, Chen YH and Sun $\mathrm{CH}$. Neomycin and puromycin affect gene expression in Giardia lamblia stable transfection. $\mathrm{Mol}$ Biochem Parasitol. 2007; 156:124-35. | Article | PubMed

\section{Citation:}

Niculescu VF. The cell system of Giardia lamblia in the light of the protist stem cell biology. Stem Cell Biol Res. 2014; 1:3.

http://dx.doi.org/10.7243/2054-717X-1-3 